NAKHODA:

JURNAL

ILMU PEMERINTAHAN
NAKHODA: JURNAL ILMU PEMERINTAHAN

Edisi Januari - Juni 2019 Volume: 18 Nomor: 1

ISSN : 1829-5827 | E-ISSN : 2656-5277

DOI : https://doi.org/10.35967/jipn

https://nakhoda.ejournal.unri.ac.id/index.php/JIPN

\title{
AKTUALISASI PERTANGGUNGJAWABAN PENGGUNAAN DANA DESA DI KABUPATEN SIAK TAHUN 2017
}

\author{
Musfita Armala Sari ${ }^{1}$, Nur Aini ${ }^{2}$, Akbar Islami $^{3}$, Rury Febrina ${ }^{3}$ \\ 1,2,3 Jurusan Ilmu Pemerintahan FISIP Universitas Riau, Pekanbaru, Indonesia \\ E-mail: musfitaarmala07@gmail.com
}

\begin{abstract}
ABSTRAK
Penelitian ini menganalisis mekanisme pertanggungjawaban Dana Desa dalam kerangka implementasi salah satu agenda dari Nawa Cita Jokowi-JK, yaitu poin ke 3 "Membangun Indonesia dari Pinggiran dengan Memperkuat Daerah-daerah dan Desa dalam Kerangka Negara Kesatuan" di desa Berumbung Baru yang diklasifikasikan sebagai Desa Maju dan Desa Tumang yang diklasfikasikan sebagai Desa tertinggal di Kabupaten SIAK, Provinsi Riau. Hasil penelitian menunjukan bahwa terdapat beberapa kesamaan dan perbedaan dalam proses pelaporan dan pertanggungjawaban antara kedua desa yang menjadi poin penilaian terhadap implementasi agenda Nawa Cita Jokowi-JK, diantara adalah mekanisme penyusunan laporan, tahapan pelaporan, dinamika yang terjadi, penilaian terhadap kebijakan.
\end{abstract}

\section{Kata Kunci: Aktualisasi, Tahapan Pertanggungjawaban, Dana Desa.}

\section{PENDAHULUAN}

Implementasi otonomi bagi desa akan menjadi kekuatan bagi pemerintah desa untuk mengurus, mengatur dan menyelenggarakan rumah tangganya sendiri, sekaligus bertambah pula beban tanggung jawab dan kewajiban desa, namun demikian penyelenggaraan pemerintahan tersebut tetap harus di pertanggungjawabkan. Desa Tumang merupakan salah satu desa yang ada di Kecamatan Siak. Desa ini terbentuk bersamaan dengan dibentuknya Kabupaten Siak yang merupakan pemekaran dari Kabupaten Bengkalis pada tahun 1999. Letaknya sangat jauh dari ibu kota kecamatan, kampung ini jauh tertinggal dari kampung-kampung yang lain yang ada di Kecamatan Siak. Desa Tumang ini merupakan desa terluas di Kecamatan Siak dengan luas wilayah 14.158,34 Ha. Warga
Tumang yang berjumlah 427 KK atau mencapai 2.122 jiwa. Keberadaan Desa Tumang di Kecamatan Siak, secara administrasi pemerintahan diakui dan menjadi bagian penduduk di Kabupaten Siak yang tinggal di Tumang. Tapi warga desa dianggap selamanya menumpang di area perizinan dan warga desa hanya memiliki hak pakai, bukan hak milik. Karena rumah yang didirikan juga tidak mendapatkan status lahan yang jelas. Semenjak dimekarkan dari kabupaten bengkalis pada tahun 1984, Desa ini belum dialiri listrik. artinya sudah 33 tahun Desa ini belum terjangkau penerangan. Berdasarkan data dari Dinas Energi dan Sumber Daya Mineral pada 2016 (sebelum dialihkan kewenangannya ke pemerintah provinsi), Tumang merupakan satu-satunya desa yang tersisa di kecamatan Siak yang belum dialiri listrik PLN. Selain itu, 
NAKHODA:

JURNAL

ILMU PEMERINTAHAN
NAKHODA: JURNAL ILMU PEMERINTAHAN

Edisi Januari - Juni 2019 Volume: 18 Nomor: 1

ISSN : 1829-5827 | E-ISSN : 2656-5277

DOI : https://doi.org/10.35967/jipn

https://nakhoda.ejournal.unri.ac.id/index.php/JIPN masyarakat Desa Tumang juga saat ini sulit mengakses jaringan telepon seluler. (www. kedesa.id)

Berumbung Baru merupakan salah satu desa yang ada di kecamatan Dayun, kabupaten Siak, provinsi Riau, Indonesia. Desa Berumbung Baru merupakan salah satu tempat pengembangan pembelajaran tim PATTIRO. PATTIRO (Pusat Telaah dan Informasi Regional) adalah sebuah organisasi non pemerintah (non government organization) yang didirikan pada tanggal 17 April 1999 di Jakarta, yang mendedikasikan aktivitasnya pada upaya mewujudkan tata pemerintahan yang baik (good governance) dan peningkatan partisipasi publik di Indonesia, terutama pada tingkat local. Desa dengan jumlah penduduk 1.962 jiwa ini tercatat punya banyak prestasi. Sejumlah keunggulan Desa Berumbung Baru yang menjadi nilai plus salah satu kampung yang terletak di Kecamatan Dayun ini, diantaranya swadaya masyarakat yang tinggi dalam pembangunan fisik Tahun 2014, mencapai Rp. 896.917.763, swadaya non fisik mencapai Rp. 2.814.368.400, kemampuan memproduksi pupuk limbah padat dari bahan dasar limbah kotoran sapi hingga 60 ton per tahun yang diprakarsai Kelompok Tani Makmur Jaya. Sistem Informasi Manajemen Desa, Profil Desa berbasis website, Sistem Informasi Alokasi Dana Desa, memiliki KUD yang sehat dengan bidang usaha bervariasi, memiliki ambulan gratis untuk masyarakat, dan modal awal Badan Usaha Milik Kampung dengan jumlah modal yang berkembang hingga hampir Rp3,5 miliar. (www. Mediaindonesia.com)

Nawa Cita Jokowi - JK adalah konsep besar untuk memajukan indonesia yang berdaulat, mandiri dan berkepribadian. Nawa Cita Jokowi-JK terdiri dari 9 agenda prioritas. Poin ke 3 pada Nawa Cita Jokowi-JK tersebut adalah "Membangun Indonesia dari Pinggiran dengan Memperkuat Daerah-daerah dan Desa dalam Kerangka Negara Kesatuan".

Berangkat dari perbedaan kondisi antara Desa Tumang dengan Desa Barumbung Baru, maka perlu dilakukan penelitian lebih lanjut mengenai bagaimana mekanisme pertanggungjawaban penggunaan Dana Desa pada desa yang diklasifikasikan sebagai desa tertinggal dan desa maju, guna mengetahui hambatan-hambatan yang dirasakan oleh kedua desa sebagai salah satu langkah dukungan dalam implementasi dari salah satu agenda Nawa Cita Jokowi-JK, sehingga pemerataan pembangunan serta maksimalisasi pemberdayaan masyarakat di desa bukan sekedar harapan semata.

Menurut Lembaga Administrasi Negara dan Badan Pengawasan Keuangan dan Pembangunan RI, akuntabilitas adalah kewajiban untuk memberikan pertanggungjawaban atau menjawab dan menerangkan kinerja dan tindakan seseorang/pimpinan suatu unit organisasi kepada pihak yang memiliki hak atau yang berwenang meminta pertanggungjawaban. Akuntabilitas adalah hal yang penting untuk menjamin nilainilai seperti efisiensi, efektifitas, reliabilitas dan prediktibilitas. Suatu akuntabilitas tidak abstrak tapi kongkrit dan harus ditentukan oleh hukum melalui seperangkat prosedur yang sangat spesifik mengenai masalah apa saja yang harus dipertanggungjawabkan. (Subroto: 2009 ).

Berkaitan dengan Dana Desa, 
NAKHODA:

JURNAL

ILMU PEMERINTAHAN
NAKHODA: JURNAL ILMU PEMERINTAHAN

Edisi Januari - Juni 2019 Volume: 18 Nomor: 1

ISSN : 1829-5827 | E-ISSN : 2656-5277

DOI : https://doi.org/10.35967/jipn

https://nakhoda.ejournal.unri.ac.id/index.php/JIPN bentuk pertanggungjawaban yang dapat dilihat adalah berupa Laporan Realisasi Penggunaan Dana Desa yang disampaikan kepada bupati/walikota setiap semester. Penyampaian laporan realisasi penggunaan Dana Desa dilakukan :

1. Untuk semester I paling lambat minggu keempat bulan Juli tahun anggaran berjalan.

2. Untuk semester II paling lambat minggu keempat bulan Januari tahun anggaran berikutnya.

Dana Desa adalah anggaran yang diperuntukkan bagi desa yang ditransfer melalui APBD kabupaten/kota untuk membiayai penyelenggaraan pemerintahan, pembangunan, pemberdayaan masyarakat, dan kemasyarakatan. Lebih lanjut dalam Pasal 74 UU Desa disebutkan, belanja desa (dimana Dana Desa menjadi sumber utama pendapatan desa) diprioritaskan untuk memenuhi kebutuhan pembangunan yang disepakati dalam musyawarah desa dan sesuai dengan prioritas pemerintah kabupaten/kota, pemerintah provinsi, dan pemerintah. Sedangkan kebutuhan pembangunan meliputi, tetapi tidak terbatas pada kebutuhan primer, pelayanan dasar, lingkungan, dan kegiatan pemberdayaan masyarakat desa. (Penjelasan UU No. 6/2014)

\section{KERANGKA TEORI}

\section{Keuangan Desa}

Keuangan desa adalah hak dan kewajiban dalam rangka penyelenggaraan pemerintahan desa yang dapat dinilai dengan uang, termasuk di dalamnya segala bentuk kekayaan yang berhubungan dengan hak dan kewajiban desa tersebut. Keuangan desa berasal dari Pendapatan Asli Desa, APBD, dan APBN. Penyelenggaraan urusan pemerintahan desa yang menjadi kewenangan desa didanai dari APBDes, bantuan pemerintah pusat, dan bantuan pemerintah daerah. Penyelenggaraan urusan pemerintah daerah yang diselenggarakan oleh pemerintah desa didanai dari APBD, sedangkan penyelenggaraan urusan pemerintah pusat yang diselenggarakan oleh pemerintah desa didanai dari APBN.

Berdasarkan Undang-Undang Nomor 6 Tahun 2014 tentang Desa, Desa mempunyai sumber pendapatan berupa pendapatan asli Desa, bagi hasil pajak daerah dan retribusi daerah kabupaten/kota, bagian dari dana perimbangan keuangan pusat dan daerah yang diterima oleh kabupaten/kota, alokasi anggaran dari APBN, bantuan keuangan dari APBD provinsi dan APBD kabupaten/kota, serta hibah dan sumbangan yang tidak mengikat dari pihak ketiga. Sumber pendapatan desa tersebut secara keseluruhan digunakan untuk mendanai desa seluruh kewenangan yang menjadi tanggung jawab desa.

\section{Dana Desa}

UU Desa mengatakan Dana Desa adalah anggaran yang diperuntukkan bagi desa yang ditransfer melalui APBD kabupaten/ kota untuk membiayai penyelenggaraan pemerintahan, pembangunan, pemberdayaan masyarakat, dan kemasyarakatan. Lebih lanjut dalam Pasal 74 UU Desa disebutkan, belanja desa (dimana Dana Desa menjadi sumber utama pendapatan desa) diprioritaskan untuk 
memenuhi kebutuhan pembangunan yang disepakati dalam musyawarah desa dan sesuai dengan prioritas pemerintah kabupaten/kota, pemerintah provinsi, dan pemerintah. Sedangkan kebutuhan pembangunan meliputi, tetapi tidak terbatas pada kebutuhan primer, pelayanan dasar, lingkungan, dan kegiatan pemberdayaan masyarakat desa.

\section{METODE PENELITIAN}

Pendekatan dalam penelitian ini menggunakan pendekatan kualitatif dengan jenis penelitian deskriptif. Penelitian dilaksanakan di dua lokasi berbeda yaitu, Kampung Berumbung Baru (kampung maju) dan Kampung Tumang (kampung tertinggal) di Kabupaten Siak.

Informasin penelitian ini adalah :

1. Kepala Seksi Pemerintahan Kampung Dinas Pemberdayaan Masyarakat dan Kampung Kabupaten Siak, Bpk. Amzirman.

2. Sekretasis Seksi Pemberdayaan Masyarakat Kampung dan Kelurahan, Ibu Eni Maryanti.

3. Camat Kecamatan Dayun, Ibu Desy Fefianti.

4. Kerani Kampung Berumbung Baru, Bpk. Hifni Sofyan.

5. Kerani Kampung Tumang, Bpk. Suprianto.

6. Ketua Bappekam Berumbung Baru, Bpk. Masjuki.

7. Kepala Urusan Keuangan Kampung Tumang, Bpk. Sevendri.

Jenis data yang dihasilkan dan instrumen yang digunakan pada penelitian, yaitu:

1. Data Primer
Data primer merupakan data yang dihasilkan melalui proses observasi dan wawancara mendalam terhadap informan penelitian.

1. Data Sekunder

Data sekunder merupakan data yang dihasilkan melalui proses pengambilan data kepada informan penelitian.

Teknik pengumpulan data yang digunakan pada penelitian ini adalah:

1. Wawancara mendalam; Wawancara yang mendalam terhadap informan guna mendapat data tentang penelitian ini. Informan kunci dalam penelitian ini terdiri dari unsur Dinas Pemberdayaan Masyarakat dan kampung, unsur perangkat Kantor Kecamatan unsur perangkat Kampung dan unsur Bappekam.

2. Dokumentasi yaitu penelitian yang dilakukan dengan cara mengumpulkan data-data yang relevan, yang dipeoleh dari buku-buku, jurnal, majalah/surat kabar yang ada kaitannya dengan penelitian.

3. Observasi; Observasi adalah kegiatan mengamati secara langsung tanpa mediator sesuatu objek untuk melihat dengan dekat kegiatan yang diakukan objek tersebut. Metode observasi memerlukan syarat-syarat tertentu agar bermanfaat bagi kegiatan riset.

Teknik analisis data yang digunakan dalam penelitian ini adalah model interaktif. Sebagaimana yang 
dikembangkan oleh Miles dan A. Michael Huberman,yaitu melalui tahapan-tahapan sebagai berikut (Burhan: 2007) :

a. Pengumpulan data yaitu data pertama atau data mentah dikumpulkan dalam satu penelitian.

b. Reduksi/penyederhanaan data yaitu proses memilih, memfokuskan, menyederhanakan, dan membuat abstraksi, mengubah data mentah yang dikumpulkan kedalam catatan yang telah disortir atau diperiksa.s

c. Penyajian data dilakukan dengan cara mendeskripsikan data yang ada secara sederhana, rinci, utuh dan interaktif yang digunakan sebagai pijakan untuk menentukan langkah berikutnya. Apabila peneliti sudah dapat menarik kesimpulan dari data yang ada apakah peneliti masih perlu melakukan penelusuran kembali sebelum menarik kesimpulan.

d. Penarikan kesimpulan/verifikasi adalah langkah terakhir yang meliputi pemberian makna data yang telah disederhanakan dan disajikan dalam penyajian data dengan cara mencatat keteraturan, pola-pola penjelasan secara logis dan metodologis konfigurasi yang memungkinkan diprediksi, hubungan sebab akibat melalui hukum-hukum empiris.

\section{HASIL DAN PEMBAHASAN}

Pelaksanaan penelitian ini telah menghasilkan suatu analisis terkait komparasi pertanggungjawaban Dana Desa antara Kampung Berumbung Baru yang diklasifikasikan sebagai Kampung maju dan Kampung Tumang yang diklasifikasikan sebagai Kampug tertinggal dalam kerangka maksimalisasi Nawa Cita Jokowi-JK. Terdapat dua tahapan dalam proses pertanggungjawaban Dana Desa, yaitu, 1) Pertanggungjawaban kepada Kepala Desa/Penghulu. 2) Pertanggungjawaban Kepala Desa/Penghulu kepada Bupati Melalui Camat.

1) Pertanggungjawaban kepada Penghulu:

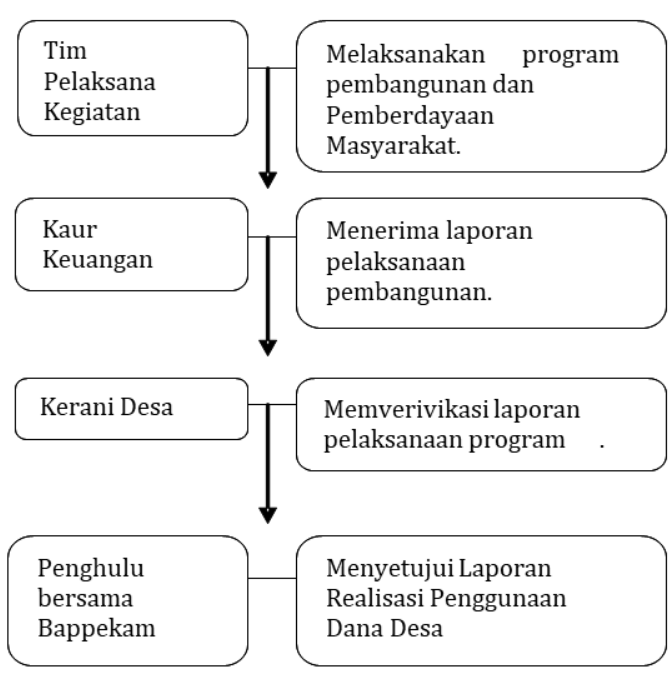

\section{Gambar 1. Strukur dan Peran Perangkat Kepenghuluan Pertanggungjawaban Dana Desa}

Pada pertanggungjawaban tahap I, terdapat beberapa tahapan yang harus dilalui dalam rangka peyetujuan Laporan Realisasi Peggunaan Dana Desa per semester yang disusun oleh Kepala Urusan Keuangan kepada Penghulu untuk dapat dilaporkan kepada Bupati melalui Camat.

$$
\begin{aligned}
& \text { 1. Pelaksanaan Kegiatan } \\
& \text { Pembangunan: }
\end{aligned}
$$


Kegiatan pembangunan dan Pemberdayaan Masyarakat dilaksanakan oleh Tim Pelaksanan Kegiatan (TPK).

2. Penerimaan Laporan Pelaksanaan Kegiatan:

Kepala Urusan Keuangan meneriman laporan terkait pelaksanaan kegiatan pembagunan dari Tim Pengelola/Pelaksana Kegiatan.

3. Verifikasi Laporan Pelaksanaan Program :
Kerani
Kampung memverifikasi laporan pelaksanaan kegiatan yang telak direkap oleh Kepala Urusan Keuangan untuk dapat diserahkan kepada Penghulu.

4. Penyetujuan Laporan

Pelaksanaan Program :

Penghulu memeriksa dan menyetujui laporan pelaksanaan program yang telah diverifikasi oleh Kerani Kampung.

1) Pertanggungjawaban Penghulu kepada Bupati melalui Camat:

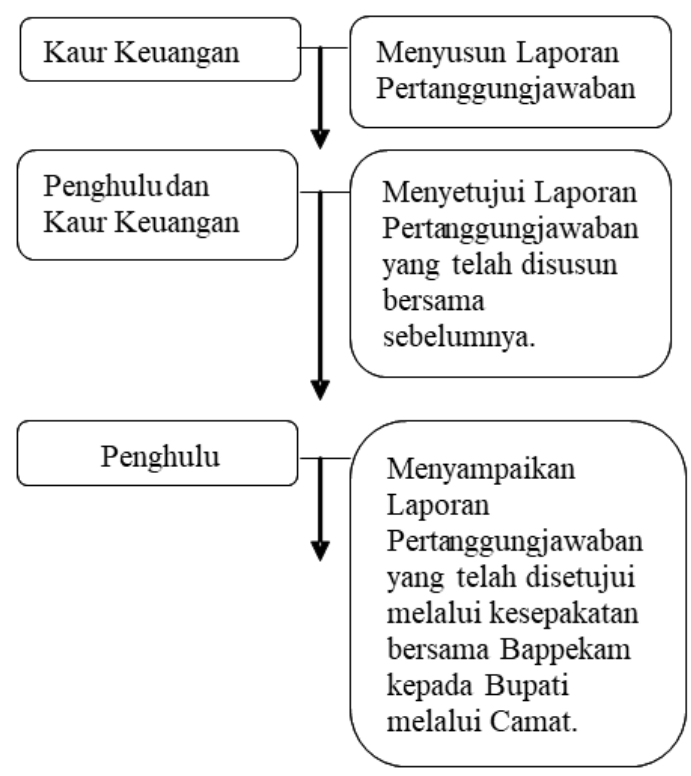

Gambar 2. Pertanggungjawaban Penghulu kepada Bupati melalui Camat

Pada pertanggungjawaban tahap II, terdapat beberapa tahapan yang juga harus dilalui dalam rangka penyampaian Laporan Realisasi Penggunaan Dana Desa kepada Bupati melalui Camat.

1. Penyusunan

Laporan

Pertanggungjawaban :

Kepala Urusan Keuangan menyusun Laporan Realisasi Penggunaan Dana Desa untuk dapat disetujui bersama dengan Penghulu. Hasil dari penelitian yang dilakukan menunjukan bahwa terdapat kecenderungan penyusunan Laporan Realisasi Penggunaan Dana Desa baik di Kampung Berumbung Baru maupun Kampung Tumang secara keseluruhan hanya dilakukan oleh Kepala Urusan Keuangan saja, sehingga pengetahuan terkait proses penyusunan laporan pertanggungjawaban serta 
dokumen yang dihasilkan (Laporan

Realisasi Penggunaan Dana Desa) secara komprehensif hanya dipahami oleh Kepala Urusan keuangan saja.

2. Penyetujuan

Laporan

Pertanggungjawaban :

Kepala Urusan Keuangan bersama dengan Penghulu menandatangani Laporan Realisasi Penggunaan Dana Desa yang telah disusun sebelumnya.

3. Penyampaian Laporan Pertanggungjawaban kepada Bupati melalui Camat:

Penghulu menyampaikan Laporan Realisasi Penggunaan Dana Desa yang telah disetujui bersama Kepala Urusan Keuangan kepada Bupati melalui Camat.

\section{KESIMPULAN}

Dari hasil analisis penelitian dapat diambil kesimpulan bahwa dalam proses pertanggungjawaban Dana Desa terdapat dua tahapan, yaitu Tahapan Pertangggungjawaban kepada Penghulu dan pertanggungjawaban Penghulu kepada Bupati melalui Camat. Pada pertnaggungjawaban tahap pertama terdiri dari empat tahapan pelaporan dan pada pertanggungjawaban tahap kedua terdiri dari tiga tahapan pelaporan

Proses penyusunan laporan pertanggungjawaban seharusnya melibatkan unsur perangkat kampung lainnya, sehingga unsur perangkat kampung secara keseluruhan memiliki pengetahuan dan wawasan terkait proses penyusunan laporan pertanggungjawaban dan bentuk dokumen yang dihasilkan, karena pada dasarnya dokumen pertanggungjawaban secara keseluruhan merupakan tanggungjawab bersama.

\section{DAFTAR PUSTAKA}

Tim Visi Yustisia. (2016). Pedoman Resmi Petunjuk Pelaksanaan Dana Desa. Jakarta: Visimedia

Soleh, Chabib. (2015). Pengelolaan keuangan Desa. Bandung: Fokusmedia

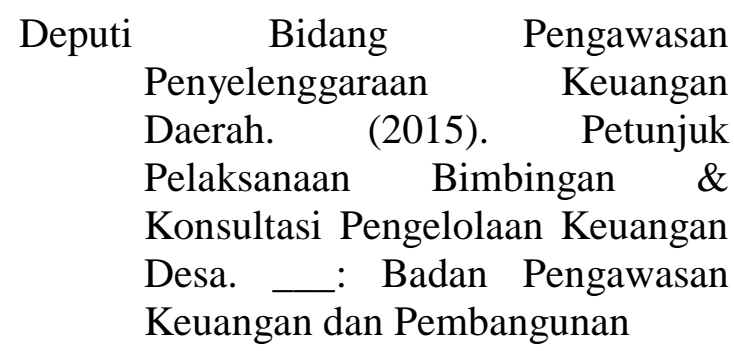

Bogong Suyanto \& Sutinah. (2007). Metode Penelitian Sosial. Jakarta: Prenada Media Group

Ashshofa, Burhan. (2007). Metode Penelitian Hukum. Jakarta: Rineka Cipta.

Hasniati. (2016). Model akuntabilitas Pengelolaan Dana Desa. Jurnal Analisis dan Pelayanan Publik. 2 (1).

\section{Internet:}

Sabrina Rizkita. (2016). Desa Barumbung Baru: Desa Unggulan di Ranah Riau. (kedesa.id). Diakses pada 8 November 2017 pukul 14.35 WIB

Antara, (2017). Desa Tumang di Siak belum Dialiri Listrik. (mediaindonesia.com). Diakses pada 13 November 2017 pukul 07.24 WIB 